\title{
A kognitív kérdőívtesztelés módszertana: mintaválasztás és toborzás ${ }^{1}$
}

\author{
Mújdricza Ferenc \\ https://doi.org/10.51624/SzocSzemle.2018.2.1 \\ Beérkezés: 2017. 10. १३. \\ Átdolgozott változat beérkezése: 2018. 03. १३. \\ Elfogadás: 2018. 04.04.
}

\begin{abstract}
Összefoglaló: A kognitív interjúzás a kérdőíves válaszadás mentális folyamatainak megfigyelése és elemzése révén lehetővé teszi a kérdőív hibáinak feltárását és a jobb kérdésmegfogalmazást. A teljes tesztfolyamat a tervezést, a tesztalanyok kiválasztását, az interjúzást, elemzést és a következtetések levonását foglalja magában. E tanulmány a kognitív teszt speciális mintaválasztási és rekrutációs elveinek bemutatására vállalkozik. A téma időszerüségét jelzi, hogy alaposabb tárgyalása nemzetközi szinten is csupán a közelmúltban kezdődött meg. A kvalitatív módszertan okán a célpopuláció (szub)kulturális változékonyságára érzékeny, célzott, kisméretű (5-50 fős), tervezett, nem reprezentatív és nem valószínúségi, kvótás mintát alkalmazunk. Az ideális dinamikus, iteratív, az elemzéssel részben paralel mintaalkotás ritkán megvalósítható, de a tanulmányban foglaltak követésével elérhető a megfelelő mintaválasztás. A mintából kizárandó csoportok kérdése, majd a tesztalanyokat nyilvántartó adatbázisra vonatkozó megfontolások kifejtése után a releváns toborzási módok jellegzetességeit, előnyeit és hátrányait tárgyalom. Általánosságban kijelenthető, hogy az egycsatornás toborzás ritkán indokolható, megfelelő minőségű minta jellemzően többcsatornás rekrutáció útján érhető el.
\end{abstract}

Kulcsszavak: kognitív teszt, interjú, mintaválasztás, tesztalany-nyilvántartás, toborzás

\section{Bevezetés}

A kognitív kérdőívtesztelés módszere az 1980-as években megjelent, észak-amerikai kutatók több tudományágon átívelő együttműködéséből kinőtt technika. A módszer elvi hátteréül szolgáló CASM-paradigma (Cognitive Aspects of Survey Methodology, pl. Jabine et al. 1984; Snijkers 2004) fókuszában a kérdőíves kutatások során a kérdések megválaszolásakor lezajló kérdezés-válaszadás kognitív folyamatai állnak. E folyamatok megértésére alapozva más kérdőív-előtesztelési módszerek mellett (pl. fókuszcsoportos tesztelés, szakértői értékelés és véleményezés, válaszadók magatartásának elemzése stb.) a kognitív tesztelés eredményei alapján optimalizált kérdőív a nagyobb érvényességű adatok produkálásán túl egyebek mellett kisebb terhet ró a válaszadókra és a kérdezőbiztosokra is. Többek között ezek miatt is terjedhetett el mára nem-

1 Köszönettel tartozom Dr. Földvári Mónikának, aki szakmai és stilisztikai javaslataival nagy szerepet játszott a tanulmány végleges szövegének kialakításában. 
zetközi szinten széles körben a survey típusú adatfelvételek általánosan romló válaszadási hajlandósága és gyengülő adatminősége elleni küzdelem egyik kulcselemeként.

A kognitív kérdőívtesztelés során az ún. kognitív interjú módszerét alkalmazzák. Ez a - nemzetközi szinten mára kiemelkedő jelentőségre szert tett - módszer lehetőséget biztosít a szakértők által összeállított kérdőív esetleges hibáinak, hiányosságainak a válaszadói oldalról történő felderítésére és fejlesztési irányvonalak kijelölésére. A kognitív interjú mint kvalitatív módszer a kinyerendő adatokat jellemzően nem számok, hanem a kevésbé absztrakt szavak, mondatok, jelentések formájában rögzíti. A kérdőívből fakadó hibák torzító hatása minimalizálható általa, így a kutatás validitásának maximalizálásában fontos szerepe van. A kognitív interjú fogalmát Beatty és Willis (2007: 288 - kiemelés az eredetiben) a következőképpen definiálják: „kérdőívvázlat kérdéseinek alkalmazása a kérdőív válaszairól további szóbeli információ gyűjtésével egyidejúleg, ami a válasz minőségének becslésére használható, illetve annak meghatározásában segít, hogy a kérdés a kérdőív szerzőjének szándéka szerinti információt generálja-e."

A kognitív interjú tehát elsősorban a kérdőív potenciális válaszadóinak mentális folyamataira fókuszál, „így lehetővé téve úgy rejtett, mint nyilvánvaló problémák azonosítását" (Collins 2015a: 14). A kognitív interjús előteszt során azt vizsgáljuk, ahogyan a kérdezés-válaszadás folyamatában a válaszadó saját érzékelése, tapasztalatai fényében interpretálja, megítéli, megválaszolja a kérdéseket, így lehetőségünk van a mérőeszköz válaszadót érintő hatáskomplexumának minél teljesebb direkt megfigyelésére.

Ugyan a kognitív interjú és a kognitív teszt fogalmait gyakran szinonimákként használják, azok nem azonos tartalmúak. Míg előbbi kizárólag a szúk értelemben vett interjúfolyamatra, utóbbi a kognitív interjú köré épülő egész projektre vonatkozik. A kognitív teszt fogalma tehát magában foglalja a teljes folyamatot a kérdezők kiválasztásától és speciális képzésétől a résztvevők (tesztalanyok²) kiválasztásán, az interjútervezetek elkészítésén át a tesztalanyokkal való szerződéskötésig és esetlegesen kutatásetikai engedélyek beszerzéséig stb. (Willis 2015).

A kognitív kérdőívtesztelés magyarországi gyakorlata a Központi Statisztikai Hivatalban immár másfél évtizedes múltra tekint vissza. Nemzetközi szinten egyre gyarapodó szakirodalmat felvonultató, sajátos módszertanának kérdéseire ezzel együtt a hazai szakirodalom mindeddig kevéssé reflektált. Jelen munka egyebek mellett az e hiátus megszüntetését is célzó tanulmányok egyike. A kognitív interjúzás és interjúelemzés módszertanának bemutatását az értelmezést segítő példákkal terjedelmi okokból további két tanulmányban adtuk közre (Földvári-Mújdricza 2018, illetve Mújdricza-Földvári 2018), így e helyütt csupán rendkívül szűken kívánok e témákra kitérni.

A kognitív interjú egyfajta ernyőfogalomnak tekinthető, mivel többféle technika

2 Willis (1994: 2) megkülönbözteti a „laboratóriumi” jellegú kognitív interjú resztvevőjét a terepmunka lekérdezettjétől. Előbbit „alanynak” (subject), míg utóbbit „válaszadónak” (respondent) nevezi. E terminológiai megkülönböztetés használata indokoltnak tekinthető, annyi kiegészítéssel, hogy a magyar nyelven túlságosan általánosan is értelmezhető, és ezért akár félreértésekre is okot adó „alany" helyett a "tesztalany” terminus alkalmazása javasolt. (Gordon B. Willis a kognitiv kérdőívtesztelés sok tekintetben úttörő szerepű, nemzetközileg elismert szaktekintélye, mára alapmúveknek számító útmutatók, tanulmányok és könyvek sorának szerzője.) 
ötvözését igényli (Collins 2015). A tesztelt kérdőív lekérdezését szimuláló interjúszituációban így - a kérdések felolvasásán túl - fő eszközeink a passzívabb think aloud (a válaszadót megkérjük, hogy „hangosan gondolkodva” magyarázza el válaszadásának folyamatát), illetve az aktívabb verbal probing (a kérdőív egyes kérdéseinél előre megírt vagy spontán tesztkérdéseket teszünk fel) technikák. Ezek mellett további kiegészítő eszközökkel is élhetünk, például megkérjük a válaszadót, hogy saját szavaival fogalmazza meg a kérdőív kérdéseit (paraphrasing), becsülje meg, mennyire biztos a válaszában (confidence rating), vagy éppen megfigyeljük a válaszadó nem tudatos viselkedését az interjúszituációban (observation) és így tovább (Willson-Miller 2014; Willis 1999, 2015; Collins 2015a; D’Ardenne 2015 stb).

Az interjútapasztalatok összegzésének, az interjúk elemzésének alapvetően kétféle megközelítése alakult ki: reparatív, kizárólag a kérdőívvel kapcsolatosan jelentkező problémákra összpontosító, és deskriptiv, ami a kérdezés-válaszadás folyamatának teljes spektrumát magába öleli. Az adatokat kódolatlan, egyszerű szöveges összefoglalók formájában és kódolt, valamilyen módszertani szempont alapján redukált formában összesíthetjük. A kódolás történhet deduktív logika mentén, valamilyen elméleti keret alapján kialakított, előre meghatározott kódok alkalmazásával, vagy induktív kutatási logikát követve. Utóbbiban az adatredukciót és az összefüggések azonosítását lehetővé tévő kódok nem előre meghatározottak - magukból az interjúszövegekből emelkednek ki (Willis 2015). A konkrét elemzési modellek részletes bemutatására terjedelmi és tartalmi okokból e helyütt nem térek ki. Az elemzés eredményeire alapozva a tesztfolyamat zárásaképpen kidolgozzuk fejlesztési javaslatainkat, így például fogalmazásbeli változtatásokat, válaszlehetőségek megváltoztatását, „javíthatatlan” kérdések teljes törlését, a kérdőív struktúrájának módosítását, vagy akár az adatgyűjtés módjának radikális megváltoztatását, esetleg további tesztelést (D’Ardenne-Collins-Blake 2015).

Mindent összevetve joggal mondhatjuk tehát, hogy egy megfelelően elvégzett kognitív teszt - már amennyiben eredményei implementálásra kerülnek - a tárgykérdőívet, az azzal gyưjtendő adatokat és így a kutatás egészét is a vizsgálati populáció számára releváns valósághoz, illetve annak a kutató számára fontos szeletéhez közelíti. E valóság percepciója, az érzékelés értelmezése, valamint megfogalmazásának módja a legritkább esetben azonos a szakértőével: lehet mélyebb, felületesebb vagy attól bármilyen más módon különböző.

Mint a legtöbb empirikus megfigyelésre épülő (társadalom)tudományos vizsgálati módszer, a kognitív tesztelés is valamilyen mintán történik. A teszt kvalitatív jellege és speciális célja miatt azonban a mintaválasztás maga is sajátos irányelveket követve kell, hogy történjen. A megfelelő tesztalanyok kiválasztásának fontosságára a témával foglalkozó szakirodalom felhívja ugyan a figyelmet (lásd pl. Willis 1994, 2005, 2015; Beatty-Willis 2007; Willson-Miller 2014; Collins 2015b; Collins-Gray 2015 stb.), de a téma alaposabb tárgyalása inkább a közelmúltban kezdődött. Korábban az alanyok kiválasztásának problémaköre meglepően kis figyelmet kapott a vonatkozó 
irodalomban (Beatty- Willis 2007; Collins 2015b). A továbbiakban a kognitív teszt mintaválasztásának irányelveit mutatom be a rendelkezésre álló szakirodalom áttekintésével és továbbgondolásával.

\section{Mintaalkotás a kognitív teszthez}

A kognitív interjú tesztalanyainak kiválasztása egyfajta implicit etnográfusi szerep felvételét is igényelheti a kutatótól, amennyiben a kiválasztás a sokaság bizonyos sajátos jellemzők által meghatározott csoportjait célozza (Gerber 1999; Willis 2005). A résztvevők kiválasztása jellemzően olyan kiválasztási stratégiákra támaszkodva történik, melyek elsődleges célja nem csupán valamilyen szempontok szerinti változatosság elérése a kiválasztott egyének jellemzői tekintetében, de annak biztosítása is, hogy a tesztalanyok a kutatás célpopulációjának megfelelően széles tartományát fedjék le (Willis 2005). A célpopuláció egyes alcsoportjai közötti kisebb vagy nagyobb, ezen alcsoportok sajátos kultúrájától függő különbségek (jelentések, értelmezések, hangsúlyeltolódások stb.) feltárása és az e különbségeket a lehetőségekhez mérten legjobban kezelni képes kérdőív összeállítása Willis (2005) szerint tehát olyan etnográfiai szemléletű kognitív interjúzást igényel, ami érzékeny a (szub)kulturális változékonyságra. A sikeres interjúzás érdekében tehát már a kiválasztás fázisában figyelmet kell szentelnünk ennek. A kérdőív témája mentén kifejezetten megcélzott csoportok tesztalanyok révén történő beemelésén túl (pl. dolgozók és munkanélküliek) lehetőleg törekednünk kell arra, hogy mintánk lefedje a populáció demográfiai és kulturális eltéréseinek természetes kiterjedését. Ezt nevezi Willis (2005: 141) kultúraközi szemléletnek.

A kognitív tesztek sajátosságai közé sorolható tehát, hogy a vizsgálati populáció kiválasztása ahhoz a populációhoz kötött, melyen a teszt révén fejleszteni kívánt kérdőívet le fogják kérdezni. Annak meghatározása pedig igen gyakran kívül esik a kognitív tesztelést végző kutatók hatáskörén.

A mintával kapcsolatos fenti igényeknek egy relatíve kisméretű, tervezett, nem reprezentatív és nem valószínűségi, kvótás minta felel meg leginkább (vö. pl. Willis 2005; Beatty-Willis 2007; Willson-Miller 2014; Collins-Gray 2015 - stb.). A mintaválasztás során arra törekszünk, hogy képesek legyünk „a populáció lehető legnagyobb keresztmetszetét meginterjúvolni problémák széles skálájának azonositása céljából”3 (Willis 2005: 140, kiemelés az eredetiben). A mintaválasztás módszere azonban ezen túlmenően nem határozható meg általánosságban. A kiválasztandó minta mérete és jellegzetességei a kérdőív jellemzőitől és a kutatás céljától függenek, és bizonyos, a mintát érintő döntések akár az interjúk elemzése során, a már megvalósult kérdőívek kiértékelésének hatására is felmerülhetnek. Ezért Willson és Miller (2014) azon az állásponton vannak, hogy a

3 Ez azonban nem biztosít semmiféle értelemben vett reprezentativitást, csupán azt, hogy amennyiben hálónkat a lehető legszélesebben „vetjük ki” a változó körülményekre, azzal maximalizáljuk a hatékony problémafelfedés esélyét (Beatty-Willis 2007). 
kognitív tesztek mintái ritkán tervezhetők meg előzetesen, a kognitív interjús vizsgálat kezdetén. A kognitív tesztek mintaválasztása tehát e tekintetben is határozottan különbözik más típusú kvalitatív interjúk mintaalkotásától.

Ha mindezek alapján általános sztenderdek kidolgozása nem is lehetséges, a kognitív interjúzás mintavételének egyfajta keretrendszere azonban felvázolható, mint azt több-kevesebb részletességgel a jelen tanulmányban hivatkozott szakirodalmak igyekeznek is megtenni.

\section{Mintaválasztás és mintaméret}

A Willson és Miller (2014: 16-17) által „tradicionálisnak” nevezett megoldás elsősorban a kérdőív kérdéseiből, céljából és szerkezetéből kiindulva határozza meg a kiválasztandó személyeket, a fent említett kultúraközi szemlélet alapján minél nagyobb lefedettséget elérve. Ez a kérdőívhez kötött jelleg, mint fent ugyancsak említettem, eltér a más kvalitatív kutatásokban megszokottaktól. A sok kvalitatív interjús adatgyüjtést érintő probléma mindazonáltal ezzel a megoldással kapcsolatban is felmerül: valójában nem tudjuk meghatározni, milyen mértékủ demográfiai diverzitás tekinthető elegendőnek. Nem lehetséges ugyanis meggyőzően alátámasztani, miért (és milyen arányban) emelünk be bizonyos csoportokat, mások pedig miért nincsenek (megfelelően) reprezentálva a mintában. A szükséges eredményeket ezért túlzottan nagyszámú alannyal történő interjúzás révén nyerhetjük csak ki.

A tesztalanyok sokféleségével szemben alternatív megoldás azok kiválasztása, akikkel az interjúzás révén valószínűsíthetően a legtöbb probléma tárható fel (e szempont ugyancsak a kvalitatív kérdőívtesztelés mintaválasztásának sajátossága). Ez esetben érdemes a kérdőív témája szerint érintett és nem érintett csoportokat is megcélozni (pl. alkoholfüggők esetén nem csupán alkoholistákat, de - bármilyen - szerfüggőség által nem érintetteket, illetve más típusú függőségben szenvedőket is), hogy a hibás negatív és a hibás pozitív válaszok is kiszűrhetők legyenek (National Center for Health Statistics 2006). Emellett a megfelelő mintaválasztás fontos kritériuma a geográfiai heterogenitás elve is. Eszerint tanácsos kerülni a tesztalanyok bizonyos meghatározott földrajzi területekről történő kiválasztását, azaz a minta geográfiai homogenitását (Willis 2005). Egy adott minta geográfiai heterogenitása/homogenitása természetesen a vizsgálati populáció földrajzi elhelyezkedésének függvénye is.

Fontos kérdés továbbá a megfelelő mintaméret meghatározása. Habár Willis (2005) szerint 12-15 interjúnál ritkán szükségeltetik több, egy ismert kognitív tesztkísérletben még 90 elvégzett interjú után is azonosítottak egyedi problémákat (Blair et al. 2006; Blair-Conrad 2011). Noha ez utóbbi esetben a nagy fontosságúnak kategorizált problémák több mint fele alacsonyabb mintaelemszámok esetén ( $\mathrm{N}=10-15)$ is azonosítható volt, a mintaelemszám növelésével további nagy fontosságú problémákra derült fény. Nem is beszélve arról, hogy a kevésbé fontos problémák negyede még $\mathrm{N}=50$-es mintaelemszámnál is észleletlen maradt.

Kisszámú kognitív interjú tehát arányaiban több nagy fontosságú problémát tár 
fel. Mindazonáltal nagyszámú interjúval összességében lényegesen több problémát tárhatunk fel, fontosabbakat és kevésbé fontosakat egyaránt. Beatty és Willis (2007) ezért az iteratív, 5-15 fős körökre osztott kognitív teszteket tekintik a legmegfelelőbbnek. A tesztkörök ideális ismétlésszámának meghatározásához a kategóriatelítettség elve kínál megoldást, aminek lényege, hogy addig a pontig ismételjük a tesztköröket, ahol már csak relatíve kevés új probléma azonosítható (Beatty-Willis 2007).

Willson és Miller (2014) a megalapozott elmélet (Grounded Theory [Glaser-Strauss 1967; Charmaz 2006]) alapján az elméleti telítettség és az elméleti relevancia elveit követik a mintaválasztásról való döntés során. Elméleti telítettség akkor valósul meg, ha a problémák, interpretációk és értelmezések teljes skáláját képesek vagyunk azonosítani és magyarázni. Amennyiben akár csak egyetlen interpretáció nem magyarázható a többi interjú kontextusában, több adatra van szükségünk. Az „egymásból magyarázhatóság” kritériuma tehát segíthet meghatározni azt a pontot, ahol biztonsággal tekinthetjük elegendőnek az elvégzett interjúk számát. Ez a pont azonban előzetesen nem megjósolható, csupán az interjúzás folyamatával párhuzamosan zajló elemzés révén azonosítható. Az elméleti relevancia a mintába kerülők változatosságára vonatkozik. Kiindulópontnak megfelelő lehet a demográfiai, illetve a kérdőív témájához kapcsolódó jellemzők szerinti kiválasztás, ahogy azonban az interpretációs minták elkezdenek kirajzolódni, a mintaválasztásnak is követnie kell azokat. Ez jellemzően egymáshoz hasonló és egymástól különböző csoportokból származó tesztalanyokkal történő kognitív interjúzás eredményeinek összehasonlításával valósítható meg.

Az optimális mintaválasztás tehát nem érhető el csupán egy előzetes elemzést követő döntés által. Az egyfázisú, az interjúzást megelőző egyszerű mechanikus kvótás mintaválasztás helyett tehát - az optimális eredmények érdekében - célszerű egy többfázisú vagy akár folyamatos, progresszív, az interjúzással jórészt párhuzamosan is zajló, organikus (ti. a zajló interjúkból kiemelkedő mintázatokra érzékenyen és rugalmasan reagáló), dinamikus mintaválasztási folyamat megvalósítása. Ez a hagyományos módon választott kiinduló mintából és az elméleti telítettség eléréséig további alanyok folyamatos bevonásából vagy több lépésben választott újabb mintákból álló mintaalkotási folyamat nyilvánvalóan nagyfokú rugalmasságot és gyors, intuitív reakciókészséget igényel mind a kutatók, mind a kutatást koordináló intézmény részéről. Ideális esetben egy - akár többkörös - kognitív teszthullám tapasztalatainak a kérdőívbe való beépítése után az egész tesztfolyamat maga is addig volna újra és újra ismételendő (a javított kérdőív hibáinak kiszűrése és javítása céljából), amíg egy igazán robusztus kérdőívet nem alkothatunk. Az itemek módosítása miatt az adatgyűjtés és adatelemzés ilyen, több hónapos vagy akár többéves időtartamon át történő kombinált alkalmazására és végül igazán alapos, átgondolt elemzés szolgáltatására azonban a gyakorlatban csak igen ritkán van lehetőségünk a statisztikai adat-előállítás szokásos keretei között (Willis 2015). A kognitív tesztek mintaalkotása tehát nem csupán mintaösszetételének meghatározottságában, de a mintaalkotási-mintavételi folyamat lezárhatóságában is a kérdőívhez kötött. Ez megkülönbözteti más, akár 
ugyancsak a Grounded Theory módszerét alkalmazó kvalitatív interjús módszerek mintavételi jellegzetességeitől.

Mindezekkel együtt azt se felejtsük el, amire az ESCAP projekt 2010-es kognitív és pilot tesztelési irányelveiben (ESCAP Statistics Division 2010: 16) hívják fel a figyelmet: a teszt egésze és hatékonysága szempontjából kisebb számú, de részletes, alapos interjú és elemzés hasznosabb, mint több, de alacsony minőségben elvégzett és elemzett interjú. Ez a szempont különösen a teszt megkezdése előtt rögzített pénzügyi keretek között dolgozó kutatók számára fontos, amennyiben a tesztelés fent leírt dinamikus mintabővüléséhez nincs pótlólagos fedezet. Bár szakértői vélemények szerint „[e]gy kognitív interjús vizsgálat szükségszerű eleme egy jól átgondolt és folytatólagos mintavételi terv" (Willson-Miller 2014: 30, kiemelés tőlem), az analízissel részben paralel módon zajló dinamikus mintaalkotási folyamat helyett a gyakorlatban a jellemzően egykörös, előre tervezett tesztalanyszámmal operáló kognitív tesztek dominálnak. A tesztelésre rendelkezésre álló idő és az elemzés szempontjai függvényében az ilyen tesztekhez 5-50 fős mintaelemszám javasolható (Snijkers 2002). Ennek felső határa a szükséges erőforrások birtokában (anyagiak, idő, elemző szakértők stb.) felfelé - mint láthattuk, akár 90-ig is - módosítható, az alsó határt képező 5-ös mintaelemszámnál kisebb minta azonban szakmailag indokolhatatlan. Nagyobb tervezett mintaelemszám és megfelelő időkeret esetén indokoltnak tűnik az 5-15 fős csoportok több körben történő tesztelésének tervezése (Beatty-Willis 2007), hogy legalább közelítőleg szimulálható legyen a dinamikus, iteratív, az elemzéssel párhuzamos mintaalkotási folyamat.

A minta tervezésénél ne feledjük azonban a teszt egészének minőségére vonatkozó általános igényt. Egy kisebb, akár az alsó határ közelében lévő mintán elvégzett, jól átgondolt és szakmailag-módszertanilag kitűnően kivitelezett teszt sokkal nagyobb eséllyel segít érvényes problémafelfedéshez, mint egy túlzottan ambiciózus méretű mintával operáló teszt gyengén kivitelezve. Az erőforrások bölcs felhasználása tehát a minta tervezésekor is fontos tényező: a teszt végeredményének megfelelő minőségéhez és a tesztelésre rendelkezésre álló erőforrásokhoz kell igazítanunk a választandó mintaméretet és mintavételi módszert (statikus, az interjúzást-analízist megelőző, vagy dinamikus, az interjúzással és elemzéssel részben párhuzamosan zajló). Az esetlegesen szúkös anyagi keretek okozta mintaválasztásbeli korlátok részben ellensúlyozhatók a magas minőségú interjúkivitelezéssel és -elemzéssel. Számolni kell azonban azzal, hogy minél közelebb vagyunk az elfogadható mintaméret nemzetközi szakirodalom és gyakorlat alapján meghatározott alsó határához (ti. 5 fô), annál nagyobb eséllyel maradnak feltáratlanul kisebb és akár nagyobb fontosságú problémák (Blair et al. 2006; Blair-Conrad 2011).

A mintaalkotás gyakorlatának a nemzetközi szakirodalomban is egyedülállóan alapos és átfogó bemutatását olvashatjuk Collins és Gray (2015) tanulmányában, ami összhangban van a fent bemutatott általános elvekkel. A továbbiakban ezt a vázlatot 
továbbgondolva mutatom be az egyes részfeladatokat és a feladatonként szükséges lépéseket.

\section{A populáció meghatározása}

A mintaalkotás első lépése a felmérés alapsokaságának meghatározása. E populáció bizonyos jellemzőinek mérésére szolgál a kognitív interjús módszerrel tesztelendő kérdőív/mérőeszköz.

\section{A mintaalkotás kritériumainak meghatározása}

Ezután a sokasági distinkciók feltárása következik, vagyis annak vizsgálata, valószínűsíthetők-e olyan különbségek a felmérés által érintett alapsokaságon belül, melyek hatással volnának arra, hogy a résztvevők hogyan válaszolnak a kérdőív kérdéseire. Amennyiben igen, mintánknak tükröznie kell a populáció ilyetén diverzitását.

A kritériumok meghatározásához mindenekelőtt háttér-információk gyújtésére van szükségünk. Feltárjuk, összegyüjtjük a tesztelendő kérdőívvel/kérdésekkel kapcsolatosan elérhető meglévő kvalitatív vagy kvantitatív adatokat, információkat, és ezek alapján azonosítjuk a mintaválasztási kritériumokat. Az ismeretek forrása hatféle lehet. Elsőként említendők a kérdőívvel vizsgálandó témáról elérhető szakirodalom vagy meglévő ismeretek, melyek rámutathatnak, milyen meghatározott jellemzőket és/vagy csoportokat kell tükröznie a mintának. Forrásként felhasználhatjuk továbbá az adatgyújtők (kérdezőbiztosok) és esetlegesen korábbi válaszadók visszajelzéseit a sokaság bizonyos alcsoportjai esetében „rosszul teljesítő” kérdések vonatkozásában. Harmadik lehetséges forrásunkként szolgálhatnak az adatok másodelemzésével nyerhető releváns eredmények, melyek a válaszmintázatoknak bizonyos alcsoportok esetében jellemző változékonyságát mutatják. Ugyancsak a mintaalkotás kritériumaihoz szükséges háttér-információk forrásául szolgálhatnak, többkörös kognitív teszt esetében, a korábbi interjúk/ körök tapasztalatai. Az utánuk következő interjúk/körök tesztalanyválasztásának kritériumait a korábbi tapasztalatok figyelembevételével kell meghatározni.

A mintaalkotási kritériumok meghatározásához az úgynevezett hozzáértő feltételezés (educated guess) az ötödik lehetséges információforrás. Amennyiben ugyanis nem áll rendelkezésünkre elegendő releváns információ, szükséges lehet szakértői feltételezéseket alkotni afelől, milyen jellemzők lehetnek hatással a kérdőív kérdéseinek megértésére vagy megválaszolására. Itt a szakértők adott felméréshez közvetlenül nem köthető megelőző ismeretei, tapasztalatai, szaktudása képezhetik azt az információs bázist, amire építve robusztus és nagy valószínűséggel (bár e valószínűség konkrétan nem meghatározható) valid mintaalkotási kritériumhipotéziseket alkothatnak. E hipotéziseket mindazonáltal nagy körültekintéssel és megfelelő indoklással kell megalkotni, ugyanis az egész tesztelési folyamat eredményességére kritikus hatással lehetnek.

Végül, de nem utolsósorban megemlítendő az esetleges kérdésverziók tekintetbevétele is, mint a mintaalkotás háttér-információinak forrása. Ha ugyanis a 
kognitív interjú célja bizonyos kérdések különböző változatainak is a tesztelése, az egyes kérdésverziók maguk is mintaalkotási kritériumokként veendők tekintetbe. Biztosítani kell tehát mindegyik változat elegendő számú interjúval történő tesztelését.

A háttér-információk összegyüjtését a priorizálás lépése követi. Bár a lehetséges tényezők alapos elemzésével akár nagyszámú mintaalkotási kritérium határozható meg, érdemes prioritási sorrendet felállítani közöttük, hogy elkerüljük a toborzás túlbonyolítását és a projekt egészének kezelhetetlen méretűvé duzzadását. $\mathrm{A}$ priorizálás folyamata során elsődleges és másodlagos kritériumcsoportokat alkothatunk. Előbbi a toborzás során mindenképpen szem előtt tartandó kritériumokat tartalmazza, utóbbi pedig a kevésbé fontos, opcionális szempontokat.

\section{Kvóták és mintaméret meghatározása}

Noha ideális esetben az elméleti telítettség, ill. „adattelítettség” eléréséig dinamikusan bővülő mintával kellene dolgoznunk, a gyakorlatban a mintaalkotás hat fő tényező mentén alakul. Ezek a következők: a kiválasztási kritériumok száma; a rendelkezésre álló anyagi keret nagysága; a rendelkezésre álló kutatói gárda létszáma; a kérdőív struktúrája - ugratások esetén biztosítandó, hogy minden kérdés megfelelő számú tesztalannyal legyen tesztelve; a rendelkezésre álló időkeret; és a kvótatípusok. Ez utóbbi tényező bővebb kifejtésre szorul, mivel két fő kvótatípus lehetséges: egymásba ágyazott, illetve párhuzamos kvóták.

A mintatervezésben az egymásba ágyazott kvóták használata a leggyakrabban alkalmazott megoldás, ahol az egyes kritériumok prioritása alapján meghatározott hierarchikus rendben az alsóbb szintek kritériumainak opciói minden felsőbb szintet bontanak. Minden szint egyes cellái egymást kizáró csoportjellemzőket határoznak meg. Az így előálló mintamátrix legalsó szintjéhez rendeljük a csoportspecifikus kvótákat, majd e kvóták összege lesz a teljes mintaelemszám.

Példaképpen lásd az alábbi, kétértékű, egymásba ágyazott kritériumrendszer által meghatározott mintamátrixot:

1. táblázat: Példa egymásba ágyazott kvótás mintamátrixra

\begin{tabular}{c|c|c|c|c|c|c|c|c} 
Kritérium & \multicolumn{9}{c|}{ Opciók } \\
\hline Nem & \multicolumn{4}{|c|}{ Férfi } & \multicolumn{3}{c}{ Nő } \\
\hline Korcsoport & \multicolumn{2}{|c|}{$18-64$} & \multicolumn{2}{|c|}{$65+$} & \multicolumn{2}{c|}{$18-64$} & \multicolumn{2}{c}{$65+$} \\
\hline Eü. állapot & beteg & $\begin{array}{c}\text { nem } \\
\text { beteg }\end{array}$ & beteg & $\begin{array}{c}\text { nem } \\
\text { beteg }\end{array}$ & beteg & $\begin{array}{c}\text { nem } \\
\text { beteg }\end{array}$ & beteg & $\begin{array}{c}\text { nem } \\
\text { beteg }\end{array}$ \\
\hline Kvóta & 8 & 10 & 10 & 10 & 8 & 10 & 10 & 10
\end{tabular}

Forrás: Collins-Gray 2015: 86 
Az egymásba ágyazott kvóták alkalmazásának előnye, hogy specifikusabb és fókuszáltabb toborzást, valamint bizonyos jellemzők által meghatározott alcsoportok elemzését teszi lehetővé. Hátránya viszont, hogy az egyes kvótáknak megfelelő tesztalanyok kiválasztása megnehezítheti a toborzást. Ezért a tervezéskor figyelembe kell venni annak lehetőségét, vajon szükséges-e minden kvótát beágyazni, ha bizonyos csoportok toborzása valószínűsíthetően túl nagy kihívást jelentene.

Bizonyos esetekben indokolt független mintaalkotási kritériumok alapján meghatározni a vizsgálandó csoportokat és azok szükséges tesztalanylétszámát, és párhuzamos kvótákat alkalmazni. Ilyen eset például, amikor a kritériumok elsősorban hozzáértő feltételezésen alapulnak, és bizonytalanok vagyunk az egymásba ágyazott kvóták esetén kialakuló alcsoportok toborzásának nehézségét illetően, vagy amikor eleve nem elvárás az alcsoportok elemzése. Ez a megoldás jellemzően mégis praktikus indokok (idő és anyagiak) nyomására szokott előtérbe kerülni. A párhuzamos kvótázásban a különböző prioritási szinteken lévő kritériumok nem bontják az összes felsőbb szintet, és nem egymást kizáróak, mint az az alábbi mintamátrixban is látható:

\section{2. táblázat: Példa párhuzamos kvótás mintamátrixra}

\begin{tabular}{|c|c|c|}
\hline Fő kritérium & Kvóták: összesen 20 interjúból az alábbi típusok & Cellahivatkozás \\
\hline \multirow{2}{*}{$\begin{array}{l}\text { (A) } \\
\text { Munkavállalói } \\
\text { háttér }\end{array}$} & 10 egyedülálló szülő, aki még sosem dolgozott & A1 \\
\hline & 10 aki dolgozott a gyermekvállalás előtt & A2 \\
\hline \multirow{2}{*}{$\begin{array}{l}\text { (B) } \\
\text { Képzettség }\end{array}$} & 10 egyedülálló szülő, aki 16 éves koráig abbahagyta a tanulmányait & B1 \\
\hline & 10, aki 17 éves kora után hagyta abba tanulmányait & B2 \\
\hline \multirow{3}{*}{$\begin{array}{l}\text { (C) } \\
\text { Legfiatalabb } \\
\text { gyermek kora }\end{array}$} & Legalább 6 egyedülálló szülő, akinek legfiatalabb gyermeke 6 év alatti & C1 \\
\hline & Legalább 6, akinek legfiatalabb gyermeke 6-10 éves & C2 \\
\hline & Legalább 6, akinek legfiatalabb gyermeke 11 éves kor feletti & C3 \\
\hline
\end{tabular}

Forrás: Collins-Gray 2015: 87

Egy konkrét interjúalany tehát akár mindhárom fő kritérium valamelyik cellájába bekerülhet.

E megoldás csupán azt tudja biztosítani, hogy minden mintaalkotási kritériumra nézve összességében megvalósuljon egy bizonyos számú interjú, miközben kifejezett kockázatként jelentkezik a homogén kvóták létrejöttének lehetősége. Ezáltal a potenciális kérdőívproblémák megfelelő feltárásának esélye csökken.

\section{A mintaalkotást befolyásoló további tényezők}

A fentieken túl bizonyos további tényezőket is figyelembe kell vennünk a mintaalkotás során. A földrajzi lefedettség tekintetében meg kell vizsgálni, hogy a tesztelendő kérdőív kérdéseinek értelmezését/megválaszolását befolyásolhatják-e földrajzi elhelyezke- 
désbeli (pl. városi/falusi) különbözőségek, illetve az anyagi és időkeret megengedi-e a különböző térségekben lefolytatandó interjúzást. Szükség lehet továbbá úgynevezett tartalékmintára. Érdemes ugyanis legalább 3-4 főnyi tartalékot képezni az esetlegesen a teszteléstől visszalépő tesztalanyok megfelelő pótlására. A tartalékminta létszáma bizonyos visszalépésre hajlamosító tényezők által befolyásoltan nagyobb is lehet, pl. amennyiben a célpopuláció kifejezetten elfoglalt. A tesztalanyok toborzásának nehézségei pedig ugyancsak felmerülhetnek a mintaalkotást befolyásoló gyakorlati tényezőkként.

\section{Nyilvántartó adatbázis}

A mintaválasztáshoz kapcsolódóan kiemelt fontosságú egy tesztalany-nyilvántartás létrehozása. Ebben az adatbázisban legalább a tesztelésre jelentkezők bizonyos alapvető demográfiai háttérjellemzői (nem, születési idő, képzettség, foglalkozás stb.), elérhetőségei, rendelkezésre állási jellemzőik (milyen napokon és/vagy napszakokban tudnak időt fordítani a tesztelésben való részvételre) rögzítésre kell, hogy kerüljenek (Snijkers 2002). E nyilvántartásba minden, az adott tesztelésben nem feltétlenül tesztelésre kerülő személy adatait rögzíteni érdemes, akik a személyes kapcsolathálón, hirdetésen vagy bizonyos csoportok megkeresésén keresztül a kiválasztás során látókörbe kerültek mint kognitív tesztben való részvételre hajlandó potenciális tesztalanyok. Ezzel a későbbi tesztelések esetén e nyilvántartás is kiválasztási csatornaként szolgálhat, természetesen a maga sajátos előnyeivel (pl. gyors, egyszerú kiválasztás) és hátrányaival (elavult adatok esélye, rekrutációs „lustaságra” hajlamosítás, vagyis az egyéb toborzási csatornák elhanyagolása stb.).

A tesztalany-nyilvántartásban való rögzítéshez a potenciális tesztalanyok előzetes engedélye szükséges, így a tesztelésben való részvétel előfeltételeként kell meghatározni az adatok ezen adatbázisban való rögzíthetőségét és az azok alapján történő kapcsolatfelvételt. Különösen fontos ugyanis kognitív vagy más (pl. fókuszcsoportos) tesztelésben már részt vett személyek esetében a megvalósult részvételek dátumainak rögzítése is. Snijkers háromnál nem több, de lehetőleg inkább két tesztelésben maximálná az egy adott személy számára megengedhető részvételek számát, s indokoltnak tűnik egy bizonyos időre - például legalább 3 évre - kizárni a tesztelésen már részt vett tesztalanyokat a kiválasztásból, hogy elkerülhető legyen a „professzionális válaszadók” megjelenésével felmerülő torzító hatás. Javasolt tehát személyenként három alkalomban maximálni a részvételt, amikre legkorábban háromévente kerülhet sor. Ez a hármas szabály mérsékelheti a személyes kapcsolatokon keresztül történő részrehajló kiválasztás veszélyét is.

A megfelelő nyomon követhetőség érdekében szükséges az adatbázisban valamilyen egyéni azonosító (pl. személyi igazolvány száma) rögzítése is a tesztelésben már részt vett személyek esetében. ${ }^{4}$

4 Az adatok kezelésével kapcsolatosan a mindenkor hatályos vonatkozó jogszabályok az irányadók. 


\section{Kizárandó csoportok}

Szakmai körökben gyakran felmerül a kérdőív-előtesztelésekből eleve kizárandó csoportok kérdése. Leggyakrabban említettek a szociológus, illetve pszichológus végzettségűek, akik a társadalomtudományos kutatási módszerekben járatos személyekként nem laikus, hanem szakértő válaszadókként kezelendők, és így válaszaik már nem a megfelelő adatokat eredményeznék.

Ezzel a megközelítéssel szemben azonban - azon túl, hogy az általam áttekintett szakirodalom a kognitív teszteléssel kapcsolatosan egyetlen szóval sem említ ilyen, képzettségi alapon eleve kizárandó csoportokat - több kritika is felvethető. Egyrészt semmi sem támasztja alá a feltételezést, hogy a szociológus/pszichológus végzettségű egyének valóban birtokában is vannak a feltételezett szakértői szerephez szükséges módszertani ismereteknek, még ha ennek valószínúsége kétségtelenül nagyobb is, mint más végzettségűek esetében. A kérdés minden kétséget kizáró eldöntéséhez valójában e személyek előzetes tesztelésére volna szükség, ami a gyakorlatban nyilvánvalóan kivitelezhetetlen.

Másrészt különösen önkényesnek tűnik éppen a szociológusok és pszichológusok mint kizárandó csoportok kiemelése. Számos társadalomtudományi és nem társadalomtudományi felsőoktatási képzésben van ugyanis jelen több-kevesebb hangsúllyal a kérdőíves kutatás módszertanának oktatása. Ahogyan akár a társadalomkutató intézetek munkatársai között is jelentős arányban szerepelhetnek a kérdőívszerkesztés módszertanában járatlan, laikusnak tekintendő személyek. Az egyes képzettségi, vagy akár munkahelyi csoportok előzetes kizárása a tesztelésből tehát önkényesnek tekinthető, így minden egyes alkalommal a minta tervezését végző szakember felelőssége az erről való döntés. Azt azonban tudomásul kell vennie, hogy maradéktalanul sosem lesz képes megindokolni ilyetén döntését, amennyiben nem teszteli a konkrét személyek valós kérdőívszerkesztési jártasságát.

Általános gyakorlati javaslatként mindenesetre megfogalmazható, hogy a valós kérdőívszerkesztési ismeretekkel és gyakorlattal valószínűsíthetően rendelkező személyek mintába emelését érdemes elkerülni. Erre vonatkozóan a kapcsolatfelvétel során vagy a hirdetésben önbevalláson alapuló ellenőrző szűrőkérdéseket lehet megfogalmazni. Megfelelő indoklással azonban adott potenciális tesztalanyok esetében (ti. a személy nagy valószínüséggel nem rendelkezik a szakértői szerepre hajlamosító ismeretekkel) e javaslat a gyakorlatban figyelmen kívül hagyható.

\section{A toborzás módszerei}

A mintaválasztás kritériumainak megfelelő személyek toborzása különböző módokon történhet, melyek mindegyike legitim módszer lehet, amennyiben biztosítható általuk az optimális eredmények elérése.

A vonatkozó szakirodalom (pl. Snijkers 2002; Willis 2005; Miller et al. 2014; Collins-Gray 2015) általában szúken tárgyalja a toborzás kérdéskörét, s nem is egységes 
a toborzási csatornák bemutatása, kategorizálása terén. Alapvetően őt fő rekrutációs csatorna különíthető el: a személyes kapcsolatrendszeren alapuló, a hirdetéses úton történő, a célcsoportok közvetlen megkeresésével operáló, a meglévő adatbázis segítségével történő, illetve valamilyen toborzási ügynökségen keresztül történő toborzás. Az alábbiakban a releváns toborzási csatornák bemutatásán túl azok lehetséges előnyeit és hátrányait is felvázolom.

Mielőtt rátérnénk e toborzási csatornák bővebb kifejtésére, megjegyzendő, hogy a potenciális tesztalanyokkal minden esetben érdemes egy rövid, lényegre törő (a részvételi hajlandóságot nem csökkentő) szűrőkérdőívet kitöltetni. Ennek révén biztosítható, hogy az adott személy valóban megfelel mintaválasztási kritériumainknak. A megfogalmazásban figyelnünk kell arra, hogy a kérdések ne tartalmazzanak olyan „vezérléseket”, melyek akár a részvételre, akár a későbbi esetleges interjúfolyamatra káros hatással volnának (Collins-Gray 2015).

\section{Személyes kapcsolatrendszeren alapuló toborzás}

A gyakorlatban a direkt toborzás valamilyen formában személyes kapcsolathálón keresztül elérhető, róluk valamilyen előzetes információ alapján célzottan megkeresett személyeket jelenti. Általánosságban a potenciális tesztalanyok személyes, telefonos vagy valamilyen üzenetben (SMS, e-mail stb.) való közvetlen felkérését takarja, ahol a kutató teszi meg aktívan az első kapcsolatfelvételt (szemben a hirdetésre való jelentkezéssel). Ennek a direkt toborzásnak alesetei a részben idetartozónak tekinthető hólabdás (amennyiben a kutató kapja meg a potenciális tesztalany elérhetőségét, és maga teszi meg az első megkeresést), valamint az azzal nagyrészt átfedésben lévő személyes kapcsolatrendszer útján történő rekrutáció. Noha elméletben a teljesen ismeretlenek felkeresése is szóba jöhetne, egy meghatározott mintavételi kritériumokkal rendelkező tesztelésnél (ami jellemzően szükséges) ez kifejezetten nem hatékony eszköz (Collins-Gray 2015), így kerülendőnek tekinthetjük.

E csatorna alkalmazásával a kutató munkatársakat és/vagy korábbi tesztalanyokat kér fel a teszt tervezése során meghatározott jellemzőknek megfelelő potenciális tesztalanyok (közvetett) ajánlására. Mi több, a kutató elvben saját (közvetlen) kapcsolathálóját is éppoly legitim módon felhasználhatja megfelelő tesztalanyok felkutatására, mint kollégái vagy korábbi tesztalanyok kapcsolathálóját, így megvalósítva akár egyfajta hólabdás jellegű toborzást. Amennyiben az egyén megfelel a kiválasztás szempontjainak, szakmailag nem indokolható a kizárása.

A módszer előnyei közé sorolható a korrespondencia (megfelelés), mivel az így választott tesztalany valós jellemzői nagyobb valószínúséggel illeszkednek a felállított demográfiai és egyéb, a kutatás sajátos céljaiból fakadó kritériumokhoz. A kutató saját kapcsolathálójából származó egyén esetén ez az előny hangsúlyosabban jelentkezik, minthogy a kritériumokat azonosító, és ezért legjobban ismerő kutató nem közvetített, hanem közvetlen információkkal rendelkezik az adott személyről (még ha ez az információ elkerülhetetlenül szubjektív megismerés és értékelés eredménye is). 
Az elkötelezettség ugyancsak a módszer előnyének tekinthető, hiszen a személyes kapcsolathálón keresztül toborzott tesztalany a kutatóval való közvetett vagy közvetlen személyes kapcsolata okán nagyobb valószínűséggel fog megjelenni a tesztelésen, illetve akadályoztatás esetén nagyobb valószínűséggel tájékoztatja a kutatót időben ahhoz, hogy hiánya a tartalékállományból pótolható legyen. A teszt során nagyobb együttműködési hajlandóságot is feltételezhetünk a közvetlen vagy közvetett módon, de személyes ismeretségen keresztül toborzott tesztalanyok részéről.

A lefedettség is a módszer előnyei közé sorolandó, hiszen nehezen elérhető vagy rejtett populációk a személyes kapcsolatrendszeren keresztül vagy hólabdás eljárással történő rekrutációval nagyobb eséllyel érhetők el (Collins-Gray 2015), mint például hirdetéses úton. Ezen túlmenően az anyagi ösztönzők által részvételre csupán nehezen vagy egyáltalán nem motiválható csoportok együttmúködését is jóval nagyobb esélylyel nyerhetjük el ezen utakon. Ez a fokozott együttmúködési potenciál elsősorban a személyes kapcsolatrendszer felhasználásával történő toborzással a kutató közvetlen, vagy legfeljebb tőle „két lépés távolságra” lévő (ti. a kutató ismeretségi körébe tartozó személy ismeretségi köréből származó) személyekkel kapcsolatban feltételezhető.

A módszer hátrányai közé tartozik egyrészt a networkspecifikus torzítás, mivel a közvetett (hólabdás) vagy közvetlen kapcsolati csatornán keresztül rekrutált tesztalanyok esetében fennáll az adott közvetítő személyek (különösen, ha maguk is személyes kapcsolatrendszer útján kerültek kiválasztásra) vagy a kutató kapcsolathálózatának az adott személyhez/kutatóhoz kötődő egyedi jellemzőinek torzító hatása, mint arra Collins és Gray (2015) is felhívják a figyelmet. Az ily módon mintába kerülő személyek esetében tehát jóval nagyobb annak veszélye, hogy a kiválasztás „kemény” (előre meghatározott, korlátozott számú, kulcsfontosságúnak ítélt) kritériumainak való megfelelés ellenére bizonyos „puha” (előre nem meghatározható) jellemzők hasonló mintázatot követnek, ezzel megjósolhatatlan és utólag nem kiszűrhető módon torzítva a teszt eredményeit.

Másrészt fennáll a geográfiai homogenitás veszélye, hiszen a kutatók, munkatársaik, korábbi tesztalanyok (különösen, ha maguk is személyes kapcsolatrendszer útján kerültek kiválasztásra) kapcsolathálózata ritkán rendelkezik megfelelően heterogén geográfiai jellemzőkkel. A szükséges geográfiai heterogenitás esélye annál kisebb, minél nagyobb a kutatás által megcélzott vizsgálati populáció elhelyezkedésének földrajzi kiterjedése. A közvetetten vagy közvetlenül, személyes kapcsolathálón keresztül toborzott tesztalanyok esetében tehát a geográfiai homogenitás fent említett torzító hatása kiemelt veszélyfaktor.

Harmadrészt megemlítendő az elfogultság lehetősége. A személyes kapcsolat következtében fennáll ugyanis a veszély, hogy a mintavételi tervet készítő, és/vagy a kiválasztást koordináló szakember saját kapcsolathálójába tartozó személy(ek) között a személyes viszonyulások észlelést és értékelést torzító (nem feltétlenül tudatos!) hatása okán a kiválasztásnál túlsúlyba kerülnek a szubjektív elemek. Így nem a legmegfelelőbb személyek kerülhetnek a mintába. Ez a veszély fokozódik, amennyiben 
kizárólag e csatornán keresztül történik a toborzás. Az elfogultság veszélye nem csupán a közvetlen, de a közvetett kapcsolatokon keresztül történő rekrutáció esetében is fennáll: ebben az esetben nem a szakember, hanem a közvetítő személy szubjektív viszonyulása a torzító faktor. Nem zárható ki a minta szándékos manipulálásának veszélye sem, vagyis bizonyos személyek vagy csoportok szakmailag nem indokolható előnyben részesítése másokkal szemben. Minthogy a kognitív tesztek tesztalanyainak közremúködését jellemzően valamilyen anyagi ellenszolgáltatással honorálják, a mintamanipulációs veszély relevanciája megkérdőjelezhetetlen.

A szubjektív torzítás nem csupán pozitív érvényú elfogultságot (részrehajlást) eredményezhet. Alkalmas személyek éppúgy kimaradhatnak a mintából a személyes viszonyulás jellegének torzító hatásából fakadóan, ahogy kevéssé alkalmasak bekerülhetnek.

Noha a személyes kapcsolatrendszeren keresztül történő kiválasztás esetében a szubjektivitás nyilvánvalóan nem kizárható, a mintaválasztásért felelős szakembereknek törekedniük kell annak minimalizálására. Megjegyzendő azonban, hogy az objektivitás mint olyan bármilyen célzott, nem reprezentatív kiválasztási forma esetében legfeljebb illuzórikus, és ilyeténképpen csupán a szubjektivitás csökkentése túzhető ki célul. A szubjektivitás teljes eliminálása elméletileg és gyakorlatilag is megvalósíthatatlan.

\section{Hirdetéses úton történō toborzás}

A megfelelő hirdetési forma kiválasztásának azon kell alapulnia, hogy milyen módon érhető el leginkább a tesztelés célpopulációja (Collins-Gray 2015). Ma már talán kevésbé gyakori megoldás a fent hivatkozott szakirodalmak által említett újsághirdetés, illetve szórólapok, vagy akár faliújságokra kihelyezett felhívások révén történő offline hirdetéses toborzás. Bizonyos célcsoportok eléréséhez azonban továbbra is szükséges lehet a használatuk. Az online (állás)hirdetések térnyerésével és dominánssá válásával mindenesetre az alkalmi munkának tekinthető, kognitív tesztelésben tesztalanyként való részvételre felhívó hirdetések is jellemzően átkerülnek a gyorsabb, könnyebb, hatékonyabb és olcsóbb hirdetési lehetőséget biztosító internetes felületekre. A kutatóintézmény így saját honlapján, közösségi oldalain, vagy akár online álláskereső portálokon stb. is meghirdetheti a felhívást. Az online és offline hirdetések elhelyezési felületének kérdésében is a célcsoportok elérésének kell az elsődleges szempontnak lennie.

Fontos a megfelelő hirdetési forma betartása, ami - más kvalitatív interjús kutatásokhoz képest - sajátos jellegzetességeket is hordoz. Ezzel kapcsolatosan általánosságban leszögezhető, hogy a nyilvánvaló pontokon túl (időpont, várható időtartam, helyszín, jelentkezés módja, határideje stb.) a projekt lényegre törő leírásának, a legfontosabb bekerülési kritériumoknak (kiket keresünk), a részvétellel vállalandó feladatok rövid leírásának, a kinyert adatok felhasználási módjának és az ellenszolgáltatás összegének és jellegének (pl. megbízási jogviszonyon keresztül) szerepelniük kell a hirdetésben (Willis 2005; Collins-Gray 2015). A hirdetés megjelenési helyét, 
nyelvezetét és formáját ajánlott a célpopulációhoz igazítani, emellett érdemes megjeleníteni a kutatóintézet vagy a kutatás stb. logóját (Collins-Gray 2015).

Hangsúlyozottan kerülendő viszont a hirdetésben bizonyos szavak, kifejezések használata, melyek a potenciális tesztalanyok tesztelés során betöltendő szerepére nézve helytelen és nemkívánatos „vezérléseket” hordoznak magukban. Ilyenek pl. a kérdőív vagy egyes kérdések véleményezése, a róluk való vélemény kikérése, továbbá a megítélés, ítélet, meglátás, vélekedés stb. szavak. A kognitív interjúzás során kerülni kell annak lehetőségét, hogy a tesztalany egyfajta laikus kérdőívszerkesztő, kérdőívértékelő szerepet vehessen fel, ez ugyanis jellemzően gyenge adatokat eredményez (Willson-Miller 2014: 22). Belátható, hogy erre már a toborzás fázisában, a tesztalanyokkal történő kommunikáció minden egyes lépcsőfokán (így a hirdetés szövegében is) érdemes különösen ügyelni, megelőzendő annak veszélyét, hogy a tesztalany egyfajta értékelő prediszpozícióval érkezzen az interjúra.

A módszer előnyei egyrészt az átláthatóság, mert minden más kiválasztási formánál nagyobb átláthatóságot biztosít, ezzel redukálja az elfogultságból eredő mintatorzítás veszélyét, másrészt pedig a heterogenitás. Megfelelően kiválasztott hirdetési módok esetén ugyanis jóval nagyobb eséllyel biztosítható a mintába kerülő személyek demográfiai, földrajzi és egyéb heterogenitása, mint más toborzási csatornák esetében. Harmadrészt ugyancsak előnyként említendő a lefedettség, hiszen megfelelően kiválasztott hirdetési módok esetén e csatorna (bizonyos speciális esetek kivételével, pl. egy adott klubba tömörülő, lokalitásában jól meghatározható és elérhető célcsoport) minden más kiválasztási formánál nagyobb esélyt kínál a célsokaság elérésére.

A módszer hátrányai közé azonban ugyancsak besorolhatjuk a lefedettség kérdését. Lefedettségi problémák leginkább egycsatornás hirdetési megoldások esetében merülhetnek fel, amennyiben az adott célcsoporthoz - annak bizonyos speciális jellemzői okán - nem jut el a hirdetés. Ilyen jellemzők pl. az internetelérés hiánya, újságolvasás hiánya, vagy akár a hasonló alkalmi munkákra való felhívások iránti érdeklődés hiánya. Bár az első két probléma csökkenthető többcsatornás hirdetés megvalósítása révén, a harmadikat kizárólag hirdetés útján nehezen lehet kezelni. Az anyagi ösztönző növelése jelenthet ugyan némi esélyt, de súlyos leegyszerúsítés volna azt feltételezni, hogy bárki ösztönözhető anyagi úton a tesztelésben való részvételre. Továbbá az anyagi javadalmazás mértéke nyilvánvalóan nem emelhető egy bizonyos, az adott kutatóintézet ráfordítási lehetőségei által meghatározott szintnél magasabbra. Ezzel az anyagilag ugyan ösztönözhető, de magas „ösztönözhetőségi küszöbbel” bíró csoportok jó eséllyel kimaradnak a jelentkezők közül. A személyes kapcsolatrendszeren keresztül történő rekrutáció minden hátrányával együtt jobb alternatívát nyújt az ilyen, hirdetés útján elérhetetlen-, és/vagy motiválhatatlan csoportok rekrutálásában.

A hirdetés mint toborzási csatorna további hátránya lehet az elfogultság, elfogult kiválasztás veszélye. A szakember ugyanis (hasonlóan a személyes kapcsolatrendszer útján történő toborzáshoz) jelentkezésre ösztönözheti a közvetett vagy közvetlen módon kapcsolathálójába tartozó személyeket, majd a beérkezett jelentkezések kö- 
zül történő végleges kiválasztásnál - szándékoltan vagy szándékolatlanul ugyan, de - érvényesülhetnek a szubjektív torzító faktorok. Ennek bizonyos mértékü kiiktatása csupán az online jelentkezés esetében biztosítható. A jelentkezők egy jelentkezési felületen viszik be adataikat, válaszolnak bizonyos szűrőkérdésekre, amivel ellenőrizhető a részvételre való alkalmasságuk, majd véletlenszerúen generált egyedi azonosítót kapnak. A kiválasztásnál csupán ezen azonosító, valamint az önbevallásos módon bevitt adatok birtokában dönt a mintaválasztásért felelős szakember a tesztalanyok kiválasztásáról. Az önbevallásos adatközlés azonban nyilván továbbra is hordoz bizonyos veszélyeket, ugyanis szándékolt mintamanipuláció esetén a kiválasztásnál előnyben részesíteni kívánt tesztalanyok előre „felkészíthetők” a „helyes” válaszok tekintetében, és így nagyobb eséllyel kerülhetnek kiválasztásra.

Megjegyzendő azonban, hogy a jelentkezésre való nem hivatalos, személyes buzdítás pozitív eredményekkel is járhat, és a személyes kapcsolatokon keresztül történő kiválasztás előnyeit becsatornázhatja e kiválasztási formába, legalább a hirdetés útján nem elérhető egyének/csoportok esetében.

\section{Célcsoportok közvetlen megkeresése - szervezetek, klubok, egyesületek, társaságok, támogató csoportok stb.}

Ez az opció annyiban hasonlít a személyes kapcsolatrendszeren keresztül történő toborzásra, hogy a mintaválasztást végző szakember keresi meg az adott csoportot, klubot a tesztelésben való részvétel ügyében. Jellemzően kisszámú jellemzők alapján jól meghatározott, e közös jellemzőkből fakadó téma köré szerveződő csoportok elérése érdekében használatos ez a toborzási csatorna, amennyiben e jellemzőknek való megfelelés kulcskritérium a kiválasztásban. Példaképpen említhető valamilyen szerfüggőséggel kapcsolatos felmérés kérdőívének tesztelése érdekében a különböző szerfüggőség(ek) mentén szerveződő önsegítő körök megkeresése, vagy éppen szabadidő-eltöltéssel kapcsolatos kutatás esetében bizonyos szabadidős tevékenységekre szerveződő klubok megkeresése stb.

Néhány jellegzetességet azonban nem árt figyelembe venni, ha valamilyen szervezetet közvetlenül keresünk fel tesztalanyok toborzásának szándékával. Segítségükért cserébe esetleg (nyíltan vagy hallgatólagosan) elvárhatnak valamilyen anyagi támogatást, netán érintettségük tudatában befolyásolni kívánhatják a kutatást. Előbbit a kutatás anyagi lehetőségeit szem előtt tartva fontoljuk meg, utóbbi viszont nem megengedhető, hacsak nem jelentenek minőségi javulást a szervezet képviselői által javasoltak a valódi a tesztfolyamatra nézve. Ezen túlmenően a szervezet javaslatot tehet segítőkész, a tesztelésben valószínűsíthetően nagyobb hajlandósággal részt vevő tagok személyére nézve, ezt azonban ugyancsak körültekintően kell kezelnünk, ragaszkodva a megfelelő tesztalanyokra vonatkozó előzetes kritériumainkhoz és kvótáinkhoz (Collins-Gray 2015).

A módszer előnyei közé tartozik a gyors és hatékony toborzás lehetősége. Ez e csatorna legfontosabb előnye, mivel a tesztelés bizonyos kritériumok alapján meghatározott 
célcsoportjai könnyen és hatékonyan érhetők el, akár nagyszámú, az adott témában releváns jellemzőkkel bíró potenciális tesztalanyt biztosítva. Előny továbbá a potenciális tesztalanyok elkötelezettsége. Minthogy e csoportok, klubok stb. tagjai a csoportban való részvételükkel már eleve aktivitást mutatnak az adott témával kapcsolatosan, valószínúsíthetően nagyobb eséllyel hajlanak a tesztelésben való részvételre, és a téma iránti elkötelezettségük okán valószínűleg kisebb eséllyel is mondják le a részvételt. Itt is feltételezhető a nagyobb együttmüködési hajlandóság a teszt során.

A módszer hátrányai egyfelől az erőforrásigény, mert jellemzően csak extenzív megelőző kutatással biztosítható a releváns szervezetek, klubok, csoportok stb. megfelelő mélységű feltérképezése, majd a szükséges kapcsolatfelvétel, egyeztetések stb., ami legalábbis időbeni erőforrásigényt növelő hatású lehet. Másfelől pedig hátránynak tekinthető az e csatornán keresztül elérhető heterogenitás (relatív) hiánya: a tisztán e csatornára korlátozott kiválasztás révén csak rendkívül nehezen - a legtöbb esetben valószínűsíthetően egyáltalán nem - biztosítható a minta szükséges demográfiai, geográfiai és egyéb jellemzők mentén tervezett heterogenitása. Ezért e csatorna elsősorban más csatornákkal együtt alkalmazandó, önmagában csak különösen indokolt esetben.

\section{Meglévő adatbázis segitségével történō toborzás}

A meglévő adatbázis segítségével történő toborzás a különböző adminisztratív adatbázisoknak, kutatási toborzási paneleknek, valamint a fent kifejtett saját tesztalany-nyilvántartó adatbázisnak a toborzásban való felhasználását jelenti (Collins-Gray 2015). Ezen adatbázisok legalább név- és elérhetőségadatokat kell-, hogy tartalmazzanak. De ha valóban hasznos toborzási csatornaként szeretnénk használni őket, további demográfiai, illetve akár az adott kognitív teszt profiljához illeszkedő (így pl. egészségi állapotra vonatkozó) adatokra is szükségünk lehet a megfelelő mintavételhez. Amenynyiben lehetőségünk van a releváns adatbázis(ok)hoz való hozzáférésre, az kifejezetten hasznos lehet a különösen sajátos csoportokat érintő interjúzás esetében, így például valamilyen egészségügyi problémában szenvedők, bizonyos oktatási programok résztvevői stb. körében végzendő kutatás kérdőívének fejlesztését célzó kognitív tesztnél. Az adatok beszerzésével és felhasználásával kapcsolatosan a mindenkor hatályos vonatkozó jogszabályok az irányadók. A kutatási toborzási panelek használata kevéssé ajánlott kognitív tesztelés esetében, ezért a továbbiakban a valamilyen adminisztratív adatbázisok, illetve saját nyilvántartó adatbázisunk mintavételi keretként való használatának bizonyos lehetséges előnyeit és hátrányait vázolom fel.

A módszer előnye a gyors, egyszerü kiválasztás lehetősége meglévő adatbázisból, különösen, ha az adott adatbázis tartalmazza a kiválasztási kritériumok által meghatározott jellegzetességekre vonatkozó adatok többségét vagy mindegyikét. További előnyt jelent a nagyobb részvételi hajlandóság esélye. Elsősorban a saját tesztalanynyilvántartó adatbázisunk esetében valószínűsíthető az átlagnál nagyobb részvételi hajlandóság, melyben eleve csupán olyan személyek vannak, akik adataiknak az adatbázisban való tárolásába beleegyeztek, és jelentkezésükkel kifejezték (egy korábbi) 
kérdőívtesztelésben való részvételi szándékukat. Adminisztratív adatbázisok esetében azonban ez az előny nem tekinthető jellemzőnek.

A módszer hátrányai között elsőként említendő az elavult adatok esélye. Minden adatbázis fő értékmérői közé sorolható ugyanis a bennük tárolt adatok „frissessége”. Ez különösen nagy volatilitású jellemzők esetében kritikus fontosságú, amennyiben ilyen jellemzők is szerepelnek tesztalany-kiválasztási kritériumaink között. E tényező is szerepet játszik abban, hogy Collins és Gray (2015) általánosságban legalább háromszor annyi személlyel javasolják a kapcsolatfelvételt e csatorna esetében, mint amennyit mintatervünk egyes kvótái meghatároznak. Ezen túlmenően a módszer rekrutációs lustaságra hajlamosíthat, mivel ha rendelkezésünkre áll egy hellyel-közzel megfelelő adatbázis, hajlamosak lehetünk elhanyagolni a többi lehetséges rekrutációs csatornát. Ezzel pedig csökkenhet a mintánkba kerülők megfelelő heterogenitásának valószínűsége, aminek torzító hatása nem megbecsülhető. Megemlítendő továbbá a módszer időigényessége. Akár hónapokig is eltarthat, mire bizonyos adatbázisokhoz hozzáférést tudunk szerezni, továbbá az adatbázis tulajdonosának (amennyiben nem saját adatbázist használunk) bizonyos kondicionális megkötései is időrablóak lehetnek (pl. a kutatás részleteivel kapcsolatos tájékoztatás) (Collins-Gray 2015).

\section{Toborzási ügynökségen keresztül történö toborzás}

Abban az esetben, ha nem rendelkezünk elegendő idővel vagy megfelelő erőforrásokkal a toborzás önálló lefolytatására, egyes szerzők megfelelő lehetőségnek tartják egy e tevékenységet ellátó cég megbízását a feladattal (Willis 2005; Collins-Gray 2015).

Külső ügynökségek megbízása esetén az alábbiakra kell különös figyelmet fordítanunk (Collins-Gray 2015). Biztosítsuk egyfelől, hogy az ügynökség megfelelően értelmezze az elvárásainkat, ehhez a toborzási protokoll egyeztetésén túl írott instrukciókat is bocsássunk rendelkezésükre. Ezután tájékozódjunk toborzási tervük felől, és tájékoztassuk őket specifikus igényeinkről, például ha el szeretnénk kerülni, hogy válaszadói panelt alkalmazzanak. Biztosítanunk kell számukra a mintaválasztási kritériumokat, a kvótákat és kutatásetikai irányelveinket is, íásos formában részletezve. Ezen túlmenően biztosítsunk számukra írott toborzási forgatókönyvet, szűrőkérdőívet, kvótatáblákat és minden szükséges egyéb toborzási dokumentumot és útmutatót, valamint tárgyaljuk meg az ösztönzőkre vonatkozó terveinket.

Amint azt Collins és Gray (2015) is megjegyzik, az ilyen, jellemzően piaci alapon múködő toborzóügynökségeknél gyakran alkalmazott válaszadói panelek esetében szignifikáns veszély, hogy a kiválasztott tesztalanyok kisebb-nagyobb arányban a hasonló kutatások (pl. terméktesztek, piackutatási fókuszcsoportok stb.) esetében jellemző ellenszolgáltatás érdekében kváziprofesszionális válaszadói tevékenységet folytató személyek lesznek, amennyiben a cég nem rendelkezik szigorú szabályokkal az egy adott személyre vonatkozó lehetséges részvételek száma tekintetében. Jellemzően ugyanis a piaci alapon múködő cégek rendkívül megengedőek e regisztereikben. Sőt; gyakran kifejezetten előnyben részesítik a kiválasztásnál a részvételre 
korábbi tapasztalatok alapján hajlamosabbnak mutatkozó személyeket. Erről tehát ugyancsak érdemes előre tájékozódnunk. A kognitív tesztelési folyamat célja ugyanis hangsúlyozottan nem olyan személyek meginterjúvolása, akik releváns tapasztalattal rendelkeznek a hasonló kérdőívek megválaszolásában (még ha ez a tapasztalat csupán „laikus tapasztalat” is). Ezzel ugyanis megbecsülhetetlen - de valószínűsíthetően nem elhanyagolható - mértékben megnő a fel nem fedezett problémák esélye, illetve a tesztalany kváziszakértői prediszpozíciójából fakadóan eleve nehézkesebb interjúfolyamatra van kilátás. A tesztfolyamat végeredményének minőségét ez akár drasztikus mértékben is ronthatja, így komolyan vehető kognitív tesztelés esetében mindent el kell követnünk, hogy elkerüljük az ilyen tesztalanyok mintába kerülését.

A módszer előnyei közül elsődleges az erőforráshiány kiváltása. Amennyiben ugyanis nem rendelkezünk a toborzás kivitelezésére (szakmailag vagy létszámban) megfelelő humánerőforrással, a közvetítő ügynökség leveszi e terheket a vállunkról. További előnyként említhető az e csatorna által biztosított időhatékonyság, de ez az előny rendkívül korlátozottan értelmezendő. Időzavarban csupán abban az esetben lehet adekvát segítség a toborzást kiszervezni külső cégnek, ha biztosítható, hogy az adott cég olyan tapasztalattal és hatékonysággal bír az elvárt minőségú toborzásban, ami reális időmegtakarítást jelenthet.

A módszer hátránya egyfelől az ellenörizhetőség problémája: e rekrutációs csatorna Achilles-sarka a kiszervezett toborzás megfelelő megvalósulásának ellenőrzése. Mindazok a veszélyek, melyek a többi kiválasztási csatorna esetében jelen vannak, a cég toborzási döntéseitől függően potenciális rizikófaktorokként jelennek meg itt is. A számunkra releváns különbség annyi, hogy a közvetlen irányításunk és befolyásunk alatt nem álló ügynökségi tevékenység következtében e rizikófaktorok feletti kontrollunk erősen közvetetté válik. Még ha minden részletre kiterjedő tervezetet adunk is át, a megfelelő színvonalú munka és az esetleges eltérések ellenőrzésére, feltárására és korrigálására a gyakorlatban vajmi kevés esélyünk van.

A szakmai alkalmasság (hiányának) kérdése is reális veszélyként merülhet fel. Minthogy az ügynökség munkatársainak kiválasztására és belső szakmai protokolljaira sincs ráhatásunk, a megfelelő minőségű toborzás feltételeinek teljesülése felől sem lehetünk biztosak. A kivitelezésre való alkalmasság esetleges hiányában hatástalan minden átadott, egyébiránt alapos és szakmailag kiváló toborzási tervezet.

Végül pedig ne felejtsük el a csatorna esetleges erőforrás-igényességét sem. Noha az ügynökségi kiszervezés eleve elsősorban humánerőforrás-hiány vagy időbeni erőforráshiány kiváltása okán merült fel, a hátrányok között megemlítendő e csatorna magasabb erőforrásigénye is. A szükséges egyeztetések akár nagyfokú időigénye, a munkaanyagok standardon túli mélységű kidolgozása (a félreérthetőség elkerülése végett), az ellenőrzésre fordítandó pluszerőforrások, végül, de nem utolsósorban a szolgáltatás anyagi vonzatai összességében akár nagyobb erőforrásigénnyel járhatnak, mint az eredetileg jelentkezett, a kiszervezést indokló erőforráshiány.

A felsorolt hátrányokat csupán egy olyan külső partner esetében tekinthetjük alacsonyabb veszélypotenciállal bírónak, amellyel minden releváns szempontból bizal- 
mas, kipróbált, szinte „szimbiotikus” kapcsolatban állunk, ahol módunk van szükség esetén a rekrutációs folyamat bármely elemére valós időben rálátni, az esetleges módosításokat akadályok nélkül keresztülvinni. Ezen túlmenően szükséges egy minden részletre kiterjedő kompenzációs megállapodás is arra az esetre, ha a toborzás bármely, a partnernél felmerülő okból kifolyólag nem elfogadható minőségben zajlana le. Mivel azonban az ilyen minőségi hiányosságokból fakadó károk megbecsülhetetlenek, az anyagi kompenzáció reális mértékének meghatározása is rendkívül nehéz. Nem is szólva az ilyen egyeztetések további erőforrásigényt növelő hatásáról, valamint a kompenzáció esetleges behajtásának későbbi nehézségeiről.

Mindezek alapján kijelenthető, hogy e csatorna lehetséges előnyeit a hátrányok és veszélyek beláthatóan nagyban meghaladják, így ezt az opciót mint rendkívül ritkán relevánsnak tűnő csatornát alapvetően kerülendőnek tekinthetjük (még ha ezzel szembe is megyünk Willis [2005], illetve Collins és Gray [2015] vonatkozó megállapításaival).

\section{Összegzés}

A kognitív teszt mintaválasztása a sikeres tesztfolyamat egyik kulcsfontosságú eleme. A megfelelő minőség biztosításához elengedhetetlen, hogy a mintaméret, a mintaalkotás módja, a toborzás stb. tekintetében lehetőségeinkhez igazodva a legmegfelelőbb döntéseket hozzuk meg. Hiába törekednénk például egy relatív kis büdzsével az ideálishoz közeli, nagymintás, dinamikus, az elemzéssel részben parallel mintaalkotásra, ha ezzel az erőforrásainkat oly mértékben merítenénk ki, hogy a megfelelő toborzásra, netán az interjúk vagy éppen az elemzés minőségi kivitelezésére nem maradna elegendő erőforrásunk. De nem csupán az anyagiak, hanem a rendelkezésünkre álló szakembergárda létszáma, releváns tapasztalata, képzettsége, terhelhetősége stb. is tágabb vagy szúkebb mozgásteret szabnak. Célunk mégis minden esetben a lehető leginkább megközelíteni az elméleti telítettséget és az elméleti relevanciát. Mintánkat, annak kritériumait és kvótáit, valamint toborzási terveinket e két vezérelv alapján kell kialakítanunk, hogy a rendelkezésünkre álló erőforrásokhoz viszonyítva a lehető legoptimálisabb tesztalanyállománnyal kezdhessünk neki az interjúzásnak.

Ha kognitív tesztelést szeretnénk végezni, gondoskodnunk kell a tesztalanyok, jelentkezők megfelelő nyilvántartásáról is. Így elkerülhetjük az ennek hiányából eredő problémákat, valamint későbbi tesztek rekrutációjához egy minden további teszteléssel bővülő csatornát építhetünk fel.

A bemutatott öt fő rekrutációs csatornán keresztül történő toborzás előnyeinek és hátrányainak összevetésével arra a következtetésre juthatunk, hogy az egycsatornás toborzás csak különösen indokolt, sajátos esetekben tekinthető megfelelő megoldásnak. Általánosságban megfogalmazható, hogy a hirdetéses út és az esetlegesen már meglévő tesztalany-nyilvántartás, illetve adminisztratív adatbázis használata a toborzásnál minden esetben indokolhatónak tűnik. Ezek mellé pedig az adott adatfelvétel jellegzetességeiből fakadóan a potenciális tesztalanyok személyes kapcsolatrendszer 
és/vagy a célcsoportok közvetlen felkeresése útján történő toborzása is beemelhető/ beemelendő. A rekrutáció külső cég felé való kiszervezése igen ritkán javasolható csatorna. Minden esetben tanácsos a toborzási csatornák előnyeinek és hátrányainak számbavétele az adott kognitív teszt céljainak, kritériumainak megfelelően.

Mindent összevetve, a helyes tesztalany-kiválasztás éppen olyan fontos eleme a kognitív tesztfolyamatnak, mint az interjúk megfelelő lefolytatása vagy az alapos elemzés. Egy jó mintaalkotás és toborzás megvalósítása tehát az első lépés a tárgykérdőív optimalizálásához vezető utunkon.

\begin{abstract}
Cognitive interviewing helps discovering questionnaire errors and composing better questions by observing and analysing the mental processes during answering a questionnaire. The full test procedure consists of planning, sampling, conducting the interviews, and the analysis, and drawing the conclusions. This study focuses on the special sampling and recruitment principles of cognitive testing. The discussion of this topic has only begun in the recent past even at the international level. Due to the qualitative methodology, a purposive, small (5-50 subjects), planned, non-representative and non-probabilistic, quota sample is to be used, which is sensitive to the (sub)cultural variability of the target population. The ideal dynamic, iterative sampling which is done partially in parallel with the analysis can rarely be carried out properly. However, appropriate sampling is possible by following the steps presented in the study. After discussing the issue of the groups to be excluded from the sample and presenting how the test subject register is to be prepared, I discuss the characteristics, the advantages, and the disadvantages of the relevant recruitment methods. As a general conclusion, single-channel recruitment is rarely reasonable, proper sample can typically be achieved through multi-channel recruitment.
\end{abstract}

Keywords: Cognitive Test, interview, sampling, test subject register, recruitment

\title{
Irodalom
}

National Center for Health Statistics (2006): Appendix 3: Cognitive Testing Interview Guide. Appendix of the Protocols for Implementing Tests of the Washington Group Short Set of Questions on Disability.

https://www.cdc.gov/nchs/data/washington_group/meeting6/appendix3_ cognitive_test.pdf. Letöltve: 2017. 06. 06.

Beatty, P. C. - Willis, G. B. (2007): Research Synthesis: The Practice of Cognitive Interviewing. Public Opinion Quarterly, 71(2): 287-311.

Blair, J. - Conrad, F. - Ackermann, A. C. - Claxton, G. (2006): The Effect of Sample Size on Cognitive Interview Findings. Előadás az American Association of Public Opinion Research éves találkozóján. Montreal, Canada.

http://www.abtassociates.com/presentations/aapor06_sample_size_cognitive_ interviews.pdf. Letöltve: 2017. 06. 06.

Blair, J. - Conrad, F. G. (2011): Sample Size for Cognitive Interview Pretesting. The Public Opinion Quarterly, 75(4): 636-658. 
Charmaz, K. (2006): Constructing Grounded Theory: A Practical Guide Through Qualitative Analysis. Thousand Oaks, CA, Sage.

Collins, D. (2015a): Cognitive interviewing: Origin, purpose and limitations. In Collins, D. (ed.): Cognitive Interviewing Practice. London: Sage, 3-27.

Collins, D. (2015b): Preface. In Collins, D. (ed.): Cognitive Interviewing Practice. London: Sage, xiv-xvi.

Collins, D. - Gray, M. (2015): Sampling and recruitment. In Collins, D. (ed.): Cognitive Interviewing Practice. London: Sage, 80-100.

D’Ardenne, J. (2015): Developing interview protocols. In Collins, D. (ed.): Cognitive Interviewing Practice. London: Sage, 101-125.

D’Ardenne, J. - Collins, D. - Blake, M. (2015): Application of findings. In Collins, D. (ed.): Cognitive Interviewing Practice. London: Sage, 175-194.

ESCAP (Economic and Social Commission for Asia Pacific Region) Statistics Division (2010): Guidelines for Cognitive and Pilot Testing of Questions For Use in Surveys. ESCAP Project on Improving Disability Measurement and Statistics in the Asia Pacific Region http://www.washingtongroup-disability.com/wpcontent/uploads/2016/02/Disability-question-testing-guidelines.pdf. Letöltve: 2017. 06. 06.

Földvári M. - Mújdricza F. (2018): A kognitív kérdőívtesztelés módszertana: a kognitív interjúfelvétel. Statisztikai Szemle, 96(5): 449-467.

Gerber, E. R. (1999): The view from anthropology: Ethnography and the cognitive interview. In Sirken, M. G. - Herrmann, D. J. - Schechter, S. - Schwarz, N. - Tanur, J. M. - Tourangeau, R. (eds.): Cognition and Survey Research. New York, NY: John Wiley \& Sons, 217-234.

Glaser, B. G. - Strauss, A. L. (1967): The Discovery of Grounded Theory: Strategies for Qualitative Research. New Brunswick \& London: AldineTransaction.

Jabine, T. - Straf, M. - Tanur, J. - Tourangeau, R. (eds.) (1984): Cognitive Aspects of Survey Methodology: Building a Bridge Between Disciplines. Washington, DC: National Academy Press.

Miller, K. - Willson, S. - Chepp, V. - Padilla, J-L. (2014): Conclusion. In Miller, K. Willson, S. - Chepp, V. - Padilla, J. L. (eds.): Cognitive Interviewing Methodology. Hoboken, NJ: John Wiley \& Sons, 153-161.

Mújdricza F. - Földvári M. (2018): A kognitív kérdőívtesztelés módszertana: a kognitív interjúk elemzése. Statisztikai Szemle, 96(6): 545-574.

Snijkers, G. J. M. E. (2002): Cognitive Laboratory Experiences: On Pre-testing Computerised Questionnaires and Data Quality. Utrecht: Universiteit Utrecht. 
Snijkers, G. (2004): Cognitive laboratory experiences and beyond: Some ideas for future research. In Prüfer, P. - Rexroth, M. - Fowler, F. J. Jr. (eds.): QUEST 2003: Proceedings of the 4th Conference on Questionnaire Evaluation Standards, 21-23 October 2003. ZUMA-Nachrichten Spezial 9. Mannheim: Zentrum für Umfragen, Methoden und Analysen (ZUMA), 190-203.

https://www.ssoar.info/ssoar/bitstream/handle/document/49210/ssoar-2004snijkers-Cognitive_laboratory_experiences_and_beyond.pdf?sequence=1. Letöltve: 2018. 03. 02.

Willis, G. B. (1999): Cognitive interviewing. A „How To” guide. Reducing Survey Error Through Research on the Cognitive and Decision Process in Surveys. Short course presented at the meeting of the American Statistical Association.

http://www.chime.ucla.edu/publications/docs/cognitive/interviewing/guide.pdf Letöltve: 2017.10.19.

Willis, G. B. (1994): Cognitive Interviewing and Questionnaire Design: A Training Manual. Cognitive Methods Staff Working Paper, Series No. 7. Hyattsville, MD: National Center for Health Statistics.

Willis, G. B. (2005): Cognitive Interviewing. A Tool for Improving Questionnaire Design. Thousand Oaks, CA, London \& New Delhi: Sage Publications.

Willis, G. B. (2015): Analysis of the Cognitive Interview in Questionnaire Design. New York, NY: Oxford University Press.

Willson, S. - Miller, K. (2014): Data collection. In Miller, K. - Willson, S. - Chepp, V. Padilla, J. L. (eds.): Cognitive Interviewing Methodology. Hoboken, NJ: John Wiley \& Sons, 15-33. 